\title{
Sustainability Matrix: Interest Groups and Ethical Theories as the Basis of Decision-Making
}

First author: Markus Vinnari, University of Tampere, School of M anagement, FI-33014 UNIVERSITY OF TAM PERE, Finland. Tel: +358 503187 603, email: markus.vinnari@uta.fi

Second author: Eija Vinnari, University of Tampere, School of Management, Fl-33014 UNIVERSITY OF TAM PERE, FINLAND. Tel. +358 503187 602, email: eija.vinnari@uta.fi

Third Author: Saara Kupsala, University of Eastern Finland, Department of Geographical and Historical Studies, Fl-80101 Joensuu, FINLAND. email: kupsala@uef.fi

\begin{abstract}
During the past few decades, the global food system has confronted new sustainability challenges related not only to public health and the environment but also to ethical concerns over the treatment of farmed animals. However, the traditional threedimensional framework of sustainable development is ill equipped to take ethical concerns related to non-human animals into account. For instance, the interests of farmed animals are often overridden by objectives associated with social, economic or environmental sustainability, despite their vast numbers and influence on contemporary societies. Moreover, sustainability policies necessarily involve an element of ethical evaluation; yet this element is not explicitly incorporated in prevailing frameworks of sustainable development. Our purpose in this article is to address these shortcomings by developing a Sustainability Matrix that recognizes the need to consider food system sustainability from the perspective of all interest groups affected by the issue under consideration, from a plurality of ethical standpoints. Combing sustainability principles with the basic idea of an ethical evaluation tool, the proposed Sustainability Matrix evaluates the sustainability of food-related systems, decisions and policies from the perspectives of three major strands of ethical theory and from the perspectives of human beings, farmed animals and wildlife. In terms of policy implications, the Sustainability Matrix can be applied in deciding on the specific targets of food system sustainability that can then be utilized as a basis for designing policies and measures towards the achievement of these goals.
\end{abstract}

\section{Introduction}

During the past few decades, the global food system ${ }^{1}$ has confronted a plethora of new sustainability challenges. In terms of social sustainability, efforts to alleviate malnutrition by producing increasing amounts of food has led to a situation where more people are being killed by overweight than underweight ( $\mathrm{Ng}$ et al. 2014; WHO 2009). At the same time, concerns related to the rise of phenomena such as climate change, loss of biodiversity, regional scarcity of fresh water supplies, and problems with the nutritional cycles (Rockström et al. 2009) have increased pressures to improve the environmental sustainability of the food system. The

\footnotetext{
${ }^{1}$ Throughout the text, we will employ the term "food system" instead of e.g." food production". This is because the implications of considering farmed animals as an interest group are not limited to the production phase but extend to other parts of the supply chain as well (e.g. transport, retail).
} 
greenhouse gas emissions generated by agriculture and especially by animal farming (Steinfeld et al. 2006) are a substantial contributor to human induced climate change. It has been estimated that global food production makes use of more than 30 percent of the ice-free land area (Aiking 2011) and agricultural products account for up to 80 percent of virtual water flows between nations (Chapagain and Hoekstra 2004). What we eat has substantial effects on global biodiversity (Burlingame and Dernini 2010).

Although public health and environmental considerations feature prominently in both academic and public discussions on food system sustainability, they are not the only challenges confronting food systems. The treatment of non-human animals, especially farmed animals, has also become a significant concern in the politicization of food in the Western world (Buller and M orris 2003; Hobson 2007). However, the traditional division of sustainability into the three domains of society, economy and environment is ill equipped to take such issues into account. One reason for this is that the cultural categorization of farmed animals can be characterized as falling somewhere in the grey area between nature and society (Franklin 1999; Tovey 2003). Despite their vast numbers (Allievi, Vinnari and Luukkanen 2015) and influence on modern society (Franklin 1999), farmed animals remain practically invisible in policy processes and thus their interests are largely disregarded when setting targets for, and assessing the impacts of, policies related to food system sustainability.

A number of situations can be envisaged where the welfare and/or rights of farmed animals would be overridden by objectives associated with the dimensions of social, economic or environmental sustainability. Such issues include, for instance, attempts to lower the costs of animal production by keeping animals in confined spaces, efforts to produce more meat through selective breeding or genetic modification of farmed animals, or initiatives to replace meat with more environmentally friendly insect-based foodstuffs despite limited knowledge of the sentience and welfare needs of insects. These are but a few examples, but they clearly illustrate the two major shortcomings of the institutionalized division of sustainable development from the perspective of food system sustainability. First, 'society', 'economy' and 'environment' are abstract and ambiguous concepts that provide little indication of the various interest groups involved in, and influenced by, sustainability-related policy-making on various societal levels. Even though the unavoidability of tradeoffs between society (or economy) and the environment have always been acknowledged (e.g. Munasinghe 1993), interest conflicts between the natural environment and non-human animals have remained largely invisible. Second, as sustainable development is a contextual, value-laden and often conflictual issue (Mebratu 1998; Hopwood, M ellor and O'Brien 2005; Ramsey 2015), sustainability policies necessarily involve an element of ethical evaluation; yet this element is not explicitly incorporated in prevailing frameworks of sustainable development. In contemporary liberal democracies characterized by value pluralism, contemplating issues from a variety of ethical standpoints is arguably crucial for sustainability-related policies to achieve legitimacy and credibility among various constituencies.

In the field of food and agricultural ethics, the necessity to consider diverse interest groups and multiple ethical standpoints has already been recognized and various frameworks have been developed to serve as theoretically informed yet practical decision-making tools. One rather widely applied tool is the Ethical M atrix originally developed for the rational ethical evaluation of food production technologies (Mepham, 1996; 2000; 2006). Yet, despite the numerous benefits and benevolent aspirations of the Ethical Matrix, its application to farmed animals is associated with certain ambiguities related to the identification of relevant interest groups and the interpretation of certain concepts. Moreover, the Ethical Matrix presents sustainability as a goal only in the case of non-sentient organisms. Therefore, the Matrix also needs to be further developed in order to be applicable to the context of food system sustainability. 
Our purpose in this article is to address these shortcomings by developing a Sustainability Matrix that recognizes the need to consider food system sustainability from the perspective of all sentient interest groups affected by the issue under consideration, from a plurality of ethical standpoints. Combing sustainability principles (Daly 1992) with the basic idea of Mepham's (1996 et seq) Ethical Matrix, our framework considers the sustainability of food-related systems, decisions and policies from the perspectives of three major strands of ethical theory and from the perspectives of human beings, farmed animals and wild life. We do not present our framew ork as the model of sustainable development but rather we hope that our proposition will provide a basis for discussing and debating the possibility of a just future shared by all forms of life.

The paper proceeds in the following fashion. In the section "Sustainability and the Food System", we elaborate on the shortcomings of the traditional sustainable development framework in the context of the food system. In the section "From Ethical M atrix to Sustainability Matrix", we first critique the Ethical Matrix and then elaborate on the ethical theories and sustainability objectives included in the proposed Sustainability Matrix. In the "Discussion" section, we present concrete examples that illustrate how the application of the Sustainability Matrix would change the outcomes of sustainability-related decisions compared to the traditional framework of sustainable development. In the final section, we offer our conclusions.

\section{Sustainability and the Food System}

Sustainable development is most often depicted as a process that enables the present generation to achieve its needs without compromising the needs of the future generations (WCED 1987). This definition has been visualized in the form of a framework that divides the associated objectives into the economic, social and environmental dimensions (M unasinghe 1993), which have since become the prevailing way to approach sustainable development issues (see Fig. 1). Despite its traction in policy spheres, this characterization of sustainable development has been deemed problematic in academic discussions for a variety of reasons including anthropocentrism (Lee, 2000; Hopwood et al., 2005); disregarding inter-species equity (Haughton, 1999); and overemphasizing economic aspects (Giddings, Hopwood and O'Brien 2002; van den Bergh, 2011). In the specific context of the food system, it has been suggested that the anthropocentrism of the traditional framework could be overcome by complementing the latter with a dimension related to non-human animal welfare and/or rights (Kidd 1992; Appleby 2005; Rawles 2010; Vinnari and Vinnari 2014). Yet, even such expanded frameworks fall short of addressing the inherent problems of the traditional framew ork mentioned in "Introduction", namely the invisibility of the various interest groups affected by sustainability policies and decisions, as well as lacking to acknowledge the unavoidable ethical evaluation associated with such decisionmaking.

\section{INSERT FIGURE 1 ABOUT HERE (SEE AT THE END OF THE TEXT)}

The low visibility of the interests of farmed animals in sustainability-related policy debates and discussions exemplifies these problems. The current numbers of these animals are staggering. Humans for example kill more than 65 billion agricultural ${ }^{2}$ animals yearly (Allievi et al. 2015), and it has been estimated that there are at least 21 billion chickens, 1.485 billion cattle and 1.169 billion sheep in the world (Cawthorn and Hoffman

\footnotetext{
${ }^{2}$ Throughout the paper, we will utilize farmed animals and agricultural animals interchangeably.
} 
2014). Concurrently with the increase in the number of farmed animals, the number of wild animals has declined drastically. During past millennia, wild megafauna's biomass has declined severely, while the biomass of humans and domestic megafauna has increased (Barnosky 2008). Currently, the biomass of farmed animals (those weighing at least $44 \mathrm{~kg}$ ) is double the human biomass and 20 times the biomass of wild megafauna (Hanski 2016), and this development is expected to continue during the next decades (Fig. 2).

\section{INSERT FIGURE 2 ABOUT HERE (SEE AT THE END OF THE TEXT)}

As concerns biodiversity, animal agriculture is an important driver of habitat loss and hence a significant cause for decline in wild animal populations (Machovina, Feeley and Ripple 2015). The population sizes of wild vertebrates for instance have declined by more than half in the past 40 years (WWF 2016). Animal agriculture is also a significant driver of the decline of large carnivores and herbivores because of habitat loss and conflict with animal agriculture (Ripple et al. 2014; Ripple et al. 2015).

Despite their large numbers and societal impact, agricultural animals have low cultural visibility in contemporary urbanized societies (O'Sullivan 2011). M ost animals are reared and killed in industrial fashion, hidden from public view (Pachirat 2011). M oreover, even though animal-derived materials are ubiquitous in present-day consumer products, the animal-origin of these products often remains invisible. Likewise, in the anthropocentric definition of sustainable development, farmed animals have appeared only as resources in the economic dimension and as a source of environmental degradation and pollution in the environmental dimension (cf. Probyn-Rapsey et al. 2016). Reducing global meat consumption, replacing ruminant meat with low-footprint animal products (such as chicken and insects), and re-integrating a small number of remaining farmed animals to agro-ecological farming systems have been considered to bring significant benefits for mitigating climate change (Wirsenius, Hedenus and Mohlin 2010) and biodiversity loss and for promoting food security (M achovina et al. 2015). However, the protection of the rights of farmed animals as beings with inherent worth has not been an objective in the traditional framing of sustainable development. This is the case even though the treatment of these animals has been called the cruelest episode in human history (Harari 2011).

The ambivalent position of farmed animals illustrates a more general rationale for revising the present framework of sustainable development towards an ethical, actor-based approach. Diverse interest groups comprising both human and non-human animals can be said to have sustainable development objectives, which are sometimes aligned and sometimes contradictory. If similarities and differences between various interest groups are not explicitly acknowledged, it becomes difficult to identify the respective sustainable development objectives, to design measures for balancing potentially conflicting goals, and to evaluate the achievement of these objectives. In addition, we consider it problematic that the ethical principles underlying the designation of the sustainability objectives are not explicitly acknowledged and discussed. We believe that incorporating interest groups and ethical theories into sustainability will pave the way for ethically balanced policies and objectives advancing food system sustainability. This is a task we will undertake in the following section.

\section{From Ethical Matrix to Sustainability Matrix}

\subsection{Overview and critique of the Ethical Matrix}


Overcoming the issues discussed above requires taking diverse interest groups and ethical theories as the starting point in decision-making related to sustainable development in the food system context. Hence, we propose a Sustainability M atrix that integrates sustainability objectives with Mepham's (1996 et seq) Ethical Matrix. Originally developed for the rational ethical assessment of biotechnological innovations in food production, the Ethical Matrix has since been applied in various cases involving food or agricultural ethics, such as fisheries/aquaculture (Millar and Tomkins 2007; Lam, 2016), genetic modification (Kaiser and Forsberg 2001; Kaiser et al. 2007) and, most interestingly for present purposes, animal sentience (M epham 2006). It has been argued that despite its "checklist" format, the Ethical Matrix can also provide a tool for structured debate and dialogue. Forsberg $(2007 \mathrm{a}, \mathrm{b})$ for instance has proposed that when employed in a pragmatic dialogical process, the Matrix can provide substantial input to a judgment by facilitating the systematic evaluation of the beneficial and unfavorable impacts on affected actors. More precisely, "it challenges those favoring an inequitable distribution of benefits and burdens to provide convincing arguments for their proposed solution" (ibid., p. 466-467). Likewise, Kaiser et al. (2007) have illustrated the applicability of the Matrix to both top-down and bottom-up approaches to decision-making processes involving both expert and lay participants. They suggest that the usefulness of Matrix lies in its ability to help participants prioritize the common good over personal, preconceived notions and thus make informed and more equitable decisions.

As the principles of the Ethical M atrix have been reviewed in a number of recent papers (e.g. Forsberg 2007a, b; Millar \& Tomkins 2007; Lam 2016), we will only recapitulate them shortly from the perspective of the present paper. The Ethical Matrix departs from Rawls' (1993) observation that liberal democracies are characterized by value pluralism; that is, they acknowledge the rights of individuals to pursue different objectives and life projects. A commitment to value pluralism implies that public value decisions cannot be made on the basis of a single ethical theory; instead, multiple standpoints need to be assessed simultaneously. To identify the set of ethical principles that are valid in a particular decision-making situation, Mepham (1996) developed the Ethical Matrix based on an approach originating from medical ethics (Beauchamp and Childress 2001). The first dimension of the Ethical M atrix incorporates three major ethical theories and principles - utilitarianism (wellbeing), Kantian deontology (autonomy) and Rawlsian theory (justice); while the second dimension comprises the relevant interest groups. Although these two dimensions provide a solid foundation for an ethically neutral evaluation tool, Mepham's (2006) application of the M atrix to biotechnological treatment of animals contains certain ambiguous points that in our view require further clarification. Below, we will elaborate on these issues and indicate how we have modified them in our proposed framework.

M epham (2006) has suggested that in cases involving animal treatment, the three broad ethical principles of wellbeing, autonomy and justice can be further specified as being respectively welfare, freedom of behavioral expression and intrinsic value. The relevant interest groups in turn would consist of the treated organism, producers, consumers and biota. The first problematic point with this suggestion is its inherent anthropocentrism as two out of the four interest groups are made up of human beings. When the Ethical $M$ atrix is thus applied in real-life decision-making without further modification, this will automatically result in over-emphasizing the (presumably mostly beneficial) impacts of animal usage on human beings. This skewed effect is further emphasized by the fact that the groups employing the Ethical $M$ atrix are likely to set more weight on the impacts of a production technology on human beings as opposed to its effects on the treated organism or biota. Animal rights activists, who could act as non-human animals' representatives are rarely, if ever, invited to join public policy committees or other official fora contemplating the sustainability of food systems. One key aim of our framework is to highlight the existence of non-human animals, 
particularly agricultural animals, so that their objectives would be taken into consideration when trying to operationalize the notion of sustainable development (cf. Vucetich and Nelson 2010) in the context of the food system. In line with this aim, we divide nonhuman beings into the two main interest groups of farmed animals and wild life, with the latter category comprising undomesticated animals ${ }^{3}$. This division reflects the diverse duties humans have toward these animal groups based on their differing relations with humans. On the one hand, humans have specific duties towards farmed animals as they have bred the latter to adapt to human societies, because of which the animals have become dependent on human beings; on the other hand, humans have duties to respect the autonomy and habitats of wild animals who live independently from the human care (Donaldson and Kymlicka 2011).

The second ambiguous point in Mepham's (2006) version of the Ethical M atrix relates to the specification of the three ethical principles in the case of farmed animals. He associates the intrinsic value of animals with Rawlsian theory and the principle of justice when in fact animals' intrinsic value is usually discussed in the context of deontology (see Regan 1985). In our view, a more appropriate location for intrinsic value is therefore as a specification of deontology. Further, we prefer to use the term "inherent value" as it underscores the independence of animals' value from human perceptions of it (Regan, 1985).

The third problematic issue relates to Mepham's (2006) discussion of animals' intrinsic value and sentience, as this discussion appears contrary to the stated neutrality aspirations of the Ethical M atrix. M ore precisely, Mepham (2006) insinuates that those striving towards a vegan world would realize their vision by immediately releasing all agricultural animals into the wild, where they would be unlikely to survive. In our view, this is a rather caricaturist depiction of the contemporary animal rights movement's strategy, and one that would need to be corroborated with empirical evidence. M oreover, Mepham (2006) refers to veganism as an extreme position, justifying this claim with an appeal to the "lengthy and expensive process of accommodation to a new order" (p. 142). However, several authoritative organizations have already concluded that in the face of the impending global sustainability crisis, inaction is no longer a choice humanity can afford (see e.g. United Nations' Sustainable Development Agenda 2030 and the Fifth Assessment Report of the Intergovernmental Panel on Climate Change). Instead of a major transition, Mepham's (2006) proposed solution is a human-animal contract that legitimates the instrumental use of animals as long as they are respectfully treated. He considers such an arrangement similar to the social contract between taxi drivers and their customers: the latter are allowed to derive instrumental value from the taxi drivers as long as the drivers do their work voluntarily, are treated respectfully and receive a fair compensation. However, when discussing a similar contract between human beings and farmed animals Mepham (2006) no longer mentions animals' voluntariness, but only their respectful treatment, as a necessary condition. In our view, the logical consequence from the acknowledgement of animals' inherent value as a deontological principle is veganism, which therefore should not be considered an extreme position.

\subsection{Sustainability Matrix}

Our proposed Sustainability Matrix is based on the three main strands of ethical theory (utilitarianism, deontology and moral egalitarianism) and the three associated sustainability objectives of efficient

\footnotetext{
${ }^{3}$ This differs from M epham's (2000) concept of biota in that our notion of wildlife only includes sentient actors. Our rationale for this choice was that securing the interests of sentient wildlife will lead to wider ecosystem conservation and/or to sustainable mutual coexistence. Yet, we are fully aware of the difficulties in determining which animals, or organisms for that matter, should have moral status and to what extent (see Jaworska \& Tannenbaum 2013).
} 
allocation, sustainable scale, and fair distribution (Daly 1992). In Table 1 and the following discussion we elaborate on each of these theories and objectives.

\section{INSRT TABLE 1 ABOUT HERE (SEE AT THE END OF THE TEXT)}

\section{Utilitarianism and efficient allocation}

The two dominant streams of ethical theory in modern philosophy are consequentialism and deontology. The main consequentialist ethical theory is utilitarianism, according to which "the morally right action is the action that produces the most good" (Driver 2014). In a traditional economic sense, utility helps to grasp the wants that a consumer has. As it is not possible to calculate the satisfaction or joy that a consumer gains from a purchase, the notion of utility is used as a proxy. If it is assumed that consumers are rational beings, they act in the market in such a way that provides them with a maximum amount of utility, and the societal aim is to achieve the most efficient markets for the consumers to act in. In sustainability literature, utilitarianism forms the basis for the principle of efficient allocation: "A good allocation is one that is efficient, i.e. that allocates resources among product end-uses in conformity with individual preferences as weighted by the ability of the individual to pay" (Daly 1992, p. 186). Considering the utilitarian foundations of the present framework of sustainable development, it is not surprising that efficiency has been the dominant sustainability objective for the past decades (Huber 2000; Princen 2005; Alcott 2008). Therefore, it will also serve as an objective in the proposed Sustainability Matrix.

In the case of human beings, we operationalize the utilitarian sustainability objective of efficient allocation as increasing the wellbeing of present and future generations. Wellbeing is a standard economic concept usually measured with the standard of living (M eade 1993). As concerns farmed animals, utilitarianism has been previously applied to make a case for increasing animal welfare (Singer, 1975), where the calculation of the utility derived from various actions includes an assessment of the pain and harm caused to animals. Although utilitarian animal ethics allows human use of animals to an extent, giving equal weighting to the interests of animals would lead to a drastic decline and major changes in the current animal use. As regards wildlife, efficient allocation can be operationalized as efficient use of resources, which, together with the inclusion of the interests of wildlife in utility calculations, would lead to a reduced use of natural resources and the preserving and enhancing of wildlife habitats.

\section{Deontology and sustainable scale}

The second main variety of ethical theory is deontology, which is interested in the specific rules that form the basis for interaction. Deontological theories "judge the morality of choices by criteria different from the states of affairs those choices bring about" (Alexander and Moore 2015). Deontological theories suggest certain rights for present and future humans and duties for present generations to respect these rights. In the context of sustainable development, future generations' right to unpolluted environment and vital ecosystem services is particularly important. This puts forwards duties for current human generations to limit their economic activity to a sustainable level in order to protect viable natural resources and the unpolluted environment for all present human communities and for future generations. In our view, this conception of moral propriety resembles the previous interpretation in the sustainability literature of scale as "the physical volume of the throughput", which implies that there is a specific level of human activity that wildlife can cope with and that this level should not be surpassed (Daly 1992, p. 186). 
In the case of human beings, we operationalize the deontological objective of sustainable scale as advancing the rights of present and future generations to an unpolluted environment. Similar thinking is evident for example in the ecological footprint calculations that offer specific limits to human activity. According to previous sustainability literature, gross national product (GNP) could be used in policy-making as a proxy to identify the sustainable scale of production (Daly 1992). Policy makers could for example set a target level GNP that should not be exceeded. In the case of farmed animals, philosophers and activists defending animal rights have presented deontologically grounded views which, when extended to animals, have been interpreted as granting them inherent value (Regan 1985). According to this interpretation, non-human animals are subjects-of-a-life and killing them is wrong. It has been argued, for example, that our increased knowledge about the abilities and qualities of different non-human animals, resulting from evolution theory, is a sufficient argument for equal consideration of non-human animals (Rachels 1990). This leads us to the main difference to the utilitarian perspective, which is interested in the treatment of animals while not questioning their use for human benefit. It has been argued that the fundamental problem in the current treatment of agricultural animals is that they are treated as economic commodities (Francione 2010). Implementing animal rights would mean that humans would question the use of farmed animals and consequently stop treating them as property (ibid.). We translate this requirement into the sustainability objective of advancing the rights of farmed animals, the successful implementation of which would lead to decreased meat consumption (Allievi et al. 2015). In the case of wildlife, we understand sufficient scale to denote the objective of limiting the land used for human purposes, which would halt the decline of habitats now taking place because of agricultural expansion and construction industries.

Moral egalitarianism and fair distribution

A third variety of ethical theories is moral egalitarianism. As a moral principle, egalitarianism strives towards equality among different actors. The egalitarian idea rests upon the doctrine "that all human persons are equal in fundamental worth or moral status" (Arneson 2013). Egalitarian discussions in modern societies are dominated by the idea that wealth and income should be more equally distributed across people (ibid.). In sustainability science literature, Daly (1992 p. 186) defines distribution as "relative division of the resource flow, as embodied in final goods and services, among alternative people" and "one in which the degree of inequality is limited within some acceptable range." Thus, in the case of human beings, the sustainability objective derived from moral egalitarianism is fair intra- and intergenerational distribution of wealth. Egalitarianism can also be used as a starting point in the evaluation of equality between humans and nonhuman animals (Vallentyne 2005). Current societies tend to be highly speciesist: non-human animals are discriminated against solely based on their non-human status, regardless of the morally relevant characters they share with humans, such as sentience (Peggs 2012). Moreover, a moral hierarchy is constructed between animals based on their usefulness and affective importance to humans (Arluke \& Sanders 1996). Likewise, animal welfare policies in Western societies are highly discriminatory: the level of protection of non-human animals is based on the public visibility and affective importance of animals, rather than on their morally relevant characters (O'Sullivan 2011). As O'Sullivan (2011: 164) writes, "[D]espite the centrality of equal consideration to the liberal democratic project, the principle is entirely absent when it comes to regulating the lives of non-human animals." In the case of agricultural animals, the sustainability objective that is based on moral egalitarianism thus calls for ethical consistency in human-animal relations. Equal consideration should be given to the interests of farmed animals based on their sentience, and they should not be discriminated against based on morally non-relevant characters, such as species, societal visibility or affective importance to humans (Bruers 2013; Allievi et al. 2015). Finally, in the case of wildlife, we operationalize moral egalitarianism as the sustainability objective of preserving biodiversity. This highlights 
that consistent treatment should also be extended to non-domesticated animals based on their sentience, similarly as in the case of farmed animals.

In the following section, we will discuss which kind of general implications the application of the proposed Sustainability M atrix would have on decision-making related to food system sustainability.

\section{Discussion}

In general terms, the major change conveyed by the Sustainability M atrix would be the need to consider food system sustainability from the perspectives of multiple interest groups and ethical theories. Such a wide approach brings to the fore interest groups and objectives that do not have a counterpart in the traditional framework of sustainable development. Table 2 presents a comparison between the Sustainability Matrix and the traditional framework depicted further above in Figure 1.

\section{INSERT TABLE 2 ABOUT HERE (SEE AT THE END OF THE TEXT)}

Starting from the interest group "wildlife", both the utilitarian objective of increasing efficiency of natural resource usage and the moral egalitarian objective of preserving biodiversity have direct, almost verbatim counterparts in the traditional framework. In contrast, there is no explicit equivalent for the deontological goal of limiting the land used for human purposes. However, as land use is associated with both natural resources and biodiversity, it might be considered in connection with these objectives.

As concerns the interest group of human beings, the utilitarian objective of increasing current and future generations' wellbeing can be perceived as the equivalent of the overarching goal of sustainable development as articulated by the Brundtland Commission (WCED 1987). That the key idea of the traditional framework is simply one of several elements in the Sustainability M atrix is a notable change in thinking, as it represents an explicit attempt to curb the traditional framework's anthropocentrism. Moreover, the inclusion of deontology and moral egalitarianism to complement utilitarianism serves to foreground aspects that have so far been considered as principles associated with tradeoffs between society and economy or environment, rather than as full-blown objectives. Deontology and its goal of sustainable scale highlight the rights of present and future human generations to an unpolluted environment, while moral egalitarianism and the associated objective of fair distribution emphasize the importance of both intra- and intergenerational distribution of wealth.

Finally, the major difference between the Sustainability M atrix and the traditional framework of sustainable development relates to farmed animals, whose interests have thus far remained largely excluded from discussions and decision-making related to food system sustainability. As can be seen from Table 2, none of the objectives associated with agricultural animals in the Sustainability Matrix has a counterpart in the traditional framework. Recently, scholars have advocated the inclusion of animal welfare as a dimension of sustainability (e.g. Rawles 2010), while food companies have also identified animal welfare as an important corporate responsibility issue (Amos and Sullivan 2017. Yet, alongside these emerging developments associated with animal welfare, the deontological goal of advancing animal rights and the moral egalitarian

\footnotetext{
${ }^{4}$ Nearly half of the world's 200 largest companies report their ethical responsibilities toward animals although they tend to approach these ethical responsibilities in consequentialist, not rights-based, terms (Janssens \& Kaptain 2016).
} 
objective of ethical consistency in human-animal relations have received very little attention in sustainability literature (but see Vinnari \& Vinnari 2014), not to mention in sustainability policies on various societal levels.

To illustrate the differences between the Sustainability M atrix and the traditional framework of sustainable development, let us consider two examples mentioned in "Introduction", namely selective breeding or genetic modification of farmed animals to increase meat yield, and the introduction of insect-based foodstuffs. It is noteworthy that our discussion of these examples should not be interpreted as an attempt to conduct comprehensive sustainability evaluations of these complex and multifaceted issues. As advised by M epham (1996 et seq), such assessments should be based on a detailed examination of a comprehensive body of scientific knowledge. Due to space limitations, such an extensive assessment is beyond the scope of the present paper.

First, selective breeding of animals has most likely taken place in one form or another as long as humankind has kept domestic animals. However, in recent decades advances in scientific knowledge and methods have enabled the breeding of animals that can be considered, as common parlance would express it, oversized. A well-known example is the Belgian Blue, a breed of beef cattle that naturally lacks myostatin, a hormone that regulates muscle growth. Because of decades of selective breeding, the Belgian Blue has grown to an extremely muscular breed, which, however, has been found to suffer from respiratory diseases and stress (Fiems 2012). In addition, 90 percent of Belgian blue calves are born by Caesarian section and some calves have too muscular tongues to suckle (Webster 2002). Contemplated in terms of the traditional framework of sustainable development, such an outcome might be deemed desirable from an economic perspective (efficient production) and perhaps even from an environmental perspective (more meat per unit of land area used for grazing) but most likely not from a societal perspective as the reduction of red meat consumption has been recommended based on public health considerations (M cM ichael, Powles and Butler 2007). In turn, the application of the Sustainability M atrix introduces even more ambiguities into the contemplation. Raising Belgian Blue cattle could still be considered to increase efficiency of natural resource usage and decrease land used for human purposes but it would contradict the objective of public health but also the objectives of animal welfare, advancing animal rights, and ethical consistency in human-animal relations. If all the cells in the Sustainability M atrix were given equal, or even close to equal, weighting for instance by a budgetary committee considering sustainability-based agricultural subsidies, raising the Belgian Blue could be deemed an unsustainable practice and subsidies withheld. Such a decision would have a direct economic effects on the profitability of the business, perhaps even to the point of re-directing production towards plant-based diets.

Our second illustrative example concerns the production of insect-based foodstuffs. Even though using insects as a source of protein is rather foreign to Western cultures, it is a traditional practice in several regions across the globe. In recent years, insect-based foodstuffs have been proposed as a complement, perhaps even a substitute, to conventional animal-derived protein sources. For example, the United Nations' Food and Agricultural Organization (FAO) has visibly advocated insect foods to reduce environmental pressures exerted by the growing global population. According to the organization (FAO/WUR 2013, p. 59), insects are a healthy, environmentally beneficial protein source due to their high food conversion rate, smaller greenhouse gas emissions and ability to feed on organic waste. FAO (ibid.) also takes issue with animal welfare, stating that insects "have few animal welfare issues, although the extent to which insects experience pain is largely unknown". From the perspective of the traditional framework of sustainable development, insect-based foodstuffs would in all likelihood be regarded as fulfilling the environmental objectives related to natural resource use and pollution as well as the socio-economic principle of securing basic needs. Again, 
assessing insect-based foods with the help of the Sustainability Matrix results in somewhat different conclusions. Although insect protein would fulfill the goals of efficient natural resource usage and limiting land use while also increasing human wellbeing, raising insects for food would raise questions related to animal welfare, animal rights and ethical consistency in human-animal relations. Research suggests insects are capable of flexible behavior and display complex navigational abilities, spatial memory, and communication skills (Barron and Klein 2016). However, scientific understanding concerning whether insects feel pain is limited (Adamo 2016). If insects were found to be sentient, a future budgetary committee contemplating whether or not to allocate research and development subsidies to firms experimenting with insect food might decide to withhold the subsidies.

As the examples above illustrate, discussions related to food system sustainability would certainly change if the Sustainability M atrix were applied in concrete decision-making situations. However, we do not claim that the application of the Sustainability Matrix would automatically result in equitable decisions. Nothing prevents those applying the Sustainability Matrix from placing different weights on each of the cells, particularly if the participants are not selected to represent a diversity of views. In an ideal world, a deliberative or decision-making body focusing on food systems sustainability would contain an equal number of members representing each of the three interest groups. In the case of farmed animals, care should be taken to include proponents of both animal welfare and animal rights since the ultimate objectives of these two groups differ largely.

\section{Conclusions}

During the past few decades, the global food system has confronted new challenges related not only to public health and the environment but also to ethical concerns over the treatment of farmed animals. However, the traditional framework of sustainable development is ill equipped to take such issues into account because of its anthropocentric starting point. Despite the vast numbers and influence of farmed animals on contemporary societies, their interests are often overridden by objectives associated with social, economic or environmental sustainability. Moreover, sustainability policies necessarily involve an element of ethical evaluation; yet this element is not explicitly incorporated in any prevailing framework of sustainable development.

To address these shortcomings, we developed the Sustainability M atrix, a framework that is inclusive to the interests of both human and non-human animals. We reviewed the application of three ethical theories utilitarianism, deontology and moral egalitarianism, as the basis for deriving the specific sustainability objectives for the three actor groups of human beings, farmed animals and wildlife.

In terms of policy implications, our Sustainability Matrix makes ethical issues related to food system sustainability transparent in such a way that both policy makers and other interested groups can influence and understand them. Outlining the ethical basis can also open up discussion concerning which groups should be responsible for advancing which type of actions. Linking ethical discussion to sustainability objectives can also assist when considering combinations of policy measures.

In our view, the Sustainability Matrix in this paper represents a plausible and well-justified tool that can be applied to improve food system sustainability, particularly in deciding on the specific targets that can then be utilized as a basis for designing policy measures towards the achievement of these goals. The framework 
is applicable on a global or national level and on the level of an individual organization, for instance as an alternative template for reporting on organizational sustainability. The Sustainability Matrix can also be applied at the beginning phases of a process for sustainability transition management (see Vinnari and Vinnari 2014).

Concerning the study's limitations, we are not claiming that the Sustainability Matrix would be a faultless panacea. Disagreements are bound to emerge regarding the weightings given to the different actors or objectives. Furthermore, it can be asked whether other sustainability principles should have been considered in addition to, or even instead of, the three discussed here. What we hope to have convincingly argued is that non-human animals deserve more attention in discussions concerning food system sustainability and that there is a need to make the contemplation of multiple ethical perspectives an explicit element of sustainable development.

\section{References}

Adamo, S.A. 2016. Do insects feel pain? A question at the intersection of animal behaviour, philosophy and robotics. Animal Behaviour, 118, 75-79.

Aiking, H. (2011). Future protein supply. Trends in Food Science \& Technology, 22(2-3), 112-120.

Alcott, B. (2008). The sufficiency objective: Would rich-world frugality lower environmental impact? Ecological Economics, 64(4), 770-786.

Alexander, L. \& Moore, M. (2015). Deontological Ethics. The Stanford Encyclopedia of Philosophy (Spring 2015 Edition), Edward N. Zalta (ed.) http:// plato.stanford.edu/archives/spr2015/entries/ ethicsdeontological/ Accessed 12 November 2015.

Allievi, F., Vinnari, M . \& Luukkanen, J. (2015). M eat consumption and production - analysis of efficiency, sufficiency and consistency of global trends. Journal of Cleaner Production, 92(1), 142-151.

Amos, N. \& Sullivan, R. (2017). The business benchmark on farm animal welfare: 2016 report. https://www.bbfaw.com/media/1450/bbfaw-2016-report.pdf. Accessed 19 April 2017.

Appleby, M. (2005). Sustainable agriculture is humane, humane agriculture is sustainable. Journal of Agricultural and Environmental Ethics, 18(3), 293-303

Arluke, A. \& Sanders, C. R. (1996). Regarding animals. Philadelphia: Temple University Press.

Arneson, R. (2013). Egalitarianism. The Stanford Encyclopedia of Philosophy (Summer 2013 Edition), Edward N. Zalta (ed.) http://plato.stanford.edu/archives/sum2013/entries/ egalitarianism/ [12 November 2015].

Barnosky, A. (2008). M egafauna biomass tradeoff as a driver of Quaternary and future extinctions. PNAS, 105(suppl. 1), 11543-11548.

Barron, A. B. \& Klein, C. 2016. What insects can tell us about the origins of consciousness. PNAS, 113 (18), 4900-4908. 
Beauchamp, T. \& Childress, J. (2001). Principles of biomedical ethics. Oxford: Oxford University Press.

Bruers, S. (2013). The Ethical Consistency of Animal Equality. Sept 2013, DRAFT. Available online (Cited 24.08.16.). https://stijnbruers.files.wordpress.com/2013/05/the-ethical-consistency-of-animalequality5.pdf.

Burlingame, B. \& Dernini, S. (2010). Sustainable diets and biodiversity - Directions and solutions for policy, research and action. Rome (Italy): Food and Agriculture Organization of the United Nations (FAO).

Buller, H. \& Morris, C. (2003). Farm animal welfare: a new repertoire of nature-society relations or modernism re-embedded? Sociologia Ruralis, 43(3), 216-237.

Cawthorn, D. \& Hoffman, L. (2014). The role of traditional and non-traditional meat animals in feeding a growing and evolving world. Animal Frontiers, 4(4), 6-12.

Chapagain, A. and Hoekstra, A. (2004). Water Footprints of Nations Vol. 1. Delft: UNESCO-IHE.

Daly, H. (1992). Allocation, distribution, and scale: towards an economics that is efficient, just, and sustainable. Ecological Economics, 6, 185-193.

Donaldson, S. \& Kymlicka, W. (2011). Zoopolis: a political theory of animal rights. Oxford: Oxford University Press.

Driver, J. (2014). The History of Utilitarianism. The Stanford Encyclopedia of Philosophy (Winter 2014 Edition), Edward N. Zalta (ed.), http:// plato.stanford.edu/archives/win2014/entries/ utilitarianism-history/ accessed 12 November 2015.

FAO/WUR 2013. Edible insects: future prospects for food and feed security. Rome: FAO.

Fiems, L. 2012. Double muscling in cattle: genes, husbandry, carcasses and meat. Animals, 2(3), 472-506.

Forsberg, E-M . (2007a). Value Pluralism and Coherentist Justification of Ethical Advice. Journal of Agricultural and Environmental Ethics, 20, 81-97.

Forsberg, E-M . (2007b). Pluralism, the ethical matrix, and coming to conclusions. Journal of Agricultural and Environmental Ethics, 20, 455-468.

Francione, G. (2010).The abolition of animal exploitation. In G. Francione \& R., Garner (Eds.), The animal rights debate. Abolition or regulation? Columbia University press, New York.

Franklin, A. (1999). Animals and modern cultures: A sociology of human-animal relations in modernity, London: Sage.

Giddings, B., Hopwood, B. \& O'Brien G. (2002). Environment, economy and so ciety: fitting them together into sustainable development. Sustainable Development, 10(4), 187-196.

Hanski, I. (2016). Tutkimusmatkoja saarille (in Finnish: Explorations to islands). Helsinki: Gaudeamus. Harari, Y. (2011). Sapiens: A brief history of humankind. Sweden: Bazar. 
Haughton, G. (1999). Environmental justice and the sustainable city. J ournal of Planning Education and Research, 18(3), 233-243.

Hobson, K. (2007). Political animals? On animals as subjects in an enlarged political geography. Political Geography, 26, 250-267.

Hopwood, B., M ellor, M . \& O'Brien, G. (2005). Sustainable development: Mapping different approaches. Sustainable Development, 13, 38-52.

Huber, J. (2000). Towards industrial ecology: Sustainable development as a concept of ecological modernization. Journal of Environmental Policy \& Planning, 2, 269-285.

Janssens, M.R.E. \& Kaptein, M. 2016. The ethical responsibility of companies towards animals: a study of the expressed commitment of the Fortune Global 200. Journal of Corporate Citizenship, 63, $42-72$.

Jaworska, A. \& Tannenbaum, J. (2013). The Grounds of M oral Status, The Stanford Encyclopedia of Philosophy (Summer 2013 Edition), Edward N. Zalta (ed.), URL = https://plato.stanford.edu/archives/sum2013/entries/grounds-moral-status/ cited 15.12.2016.

Kaiser, M . \& Forsberg, E-M . (2001). Assessing Fisheries - Using an Ethical M atrix in a Participatory Process. Journal of Agricultural and Environmental Ethics, 14, 191-200.

Kaiser, M., M illar, K., Thorstensen, E. and Tomkins, S. (2007). Developing the Ethical M atrix as a decision support framework: GM fish as a case study. Journal of Agricultural and Environmental Ethics, 20, 65-80.

Kidd, C. (1992). The evolution of sustainability. Journal of Agricultural and Environmental Ethics, 5(1), 1-26.

Lam, M. (2016). The ethics and sustainability of capture fisheries and aquaculture. Journal of Agricultural and Environmental Ethics, 29, 35-65.

Lee, K. (2000). Global sustainable development: its intellectual and historical roots. In K. Lee, A. Holland, D. M cNeill (Eds.), Global sustainable development in the 21st century (pp. 31-47). Edinburgh: Edinburgh University Press.

M achovina, B., Feeley, K. \& Ripple, W. (2015). Biodiversity conservation: The key is reducing meat consumption. Science of the Total Environment, 536, 419-431.

M cM ichael, J., Powles C. \& Butler R., (2007). Food, livestock production, energy, climate change, and health. Lancet, 370, 1253-1263.

Meade, J. (1993). Liberty, equality and efficiency. New York: NYU Press.

M ebratu, D. (1998). Sustainability and sustainable development: Historical and conceptual review. Environmental Impact Assessment Review, 18(6), 493-520.

Mepham, B. (1996) Ethical analysis of food biotechnologies: an evaluative framework. In B. M epham (Ed.), Food ethics (pp. 101-119). London: Routledge.

M epham, T. B. (2000). A framework for the ethical analysis of novel foods: the ethical matrix. Journal of Agricultural and Environmental Ethics, 12, 165-176. 
M epham, T. B. (2006). The ethical matrix as a decision-making tool with specific reference to animal sentience. In J. Turner \& J. D'Silva (Eds.), Animals, ethics and trade (pp. 134-145). London: Earthscan.

M illar, K. and Tomkins, S. (2007). Ethical Analysis of the Use of GM Fish: Emerging Issues for Aquaculture Development. Journal of Agricultural and Environmental Ethics, 20(5), 437-453.

M unasinghe, M. (1993). Environmental Economics and Sustainable Development, Environment paper No. 3. World Bank: Washington DC.

Ng, M., Fleming, T., Robinson, M., Thompson, B., Graetz, N., et al. (2014). Global, regional, and national prevalence of overweight and obesity in children and adults during 1980-2013: a systematic analysis for the Global Burden of Disease Study 2013. The Lancet, 384(9945), 766-781.

O'Sullivan, S. (2011). Animals, equality and democracy. Basingstoke: Palgrave Macmillan.

Pachirat, T. (2011). Every twelve seconds: Industrialized slaughter and the politics of sight. New Haven: Yale University Press.

Peggs, K. (2012). Animals and sociology. Basingstoke: Palgrave M acmillan.

Princen, T. (2005). The logic of sufficiency. Cambridge: M IT Press.

Probyn-Rapsey, F., Donaldson, S., Loannides, G., Lea, T., Marsh, K., Neimanis, A. Potts, A. Taylor, N., Twine, R., Wadiwel, D. \& White, S. (2016). A sustainable campus: The Sydney declaration on interspecies sustainability. Animal Studies Journal, 5(1), 110-151.

Rachels, J. (1990). Created from animals - the moral implications of Darwinism. Oxford: Oxford University Press.

Ramsey, J. (2015). On not defining sustainability. Journal of Agricultural and Environmental Ethics, 28, 1075-1087.

Rawles, K., (2010). Developing ethical, sustainable and compassionate food policies. In J. D'Silva \& J. Webster (Eds.), The meat crisis: Developing more sustainable production and consumption. London: Earthscan.

Rawls, J. (1993). Political liberalism. New York: Columbia University Press.

Regan, T. (1985). The case for animal rights. Berkeley: University of California Press.

Ripple, W.J., J.A. Estes, R.L. Beschta, C.C. Wilmers, E.G. Ritchie, M. Hebblewhite, J. Berger, B. Elmhagen, M. Letnic, M .P. Nelson, O.J. Schmitz, D.W. Smith, A.D. Wallach \& A.J. Wirsing (2014). Status and ecological effects of the world's largest carnivores. Science, 343(6167), 1241484.

Ripple, W.J., T.M . Newsome, C. Wolf, R. Dirzo, K.T. Everatt, M. Galetti, M.W. Hayward, G.I.H. Kerley, T. Levi, P.A. Lindsey, D.W. Macdonald, Y. M alhi, L.E. Painter, C.J. Sandom, J. Terborgh and B. Van Valkenburgh (2015.) Collapse of the world's largest herbivores. Science Advances, 1(4), 1-12.

Rockström, J., Steffen, W., Noone, K., Persson, A., Chapin, F., Lambin, E., et al. (2009). A safe operating space for humanity. Nature, 461, 472-475. 
Singer, P. (1975). Animal liberation: A new ethics for our treatment of animals. New York: Random House.

Steinfeld, H., Gerber, P., Wassenaar, T., Castel, V. \& Haan, C. (2006). Livestock's long shadow:

Environmental issues and options. Rome: Food and Agriculture Organization of the United Nations.

Tovey, H. (2003). Theorising nature and society in sociology: The invisibility of animals. Sociologia Ruralis, 43(3), 196-215.

Vallentyne, P. (2005). Of mice and men: equality and animals. Journal of Ethics, 9, 403-433.

van den Bergh, J. (2011). Environment versus growth - A criticism of "degrowth" and a plea for "agrowth". Ecological Economics, 70, 881-890.

Vinnari M. \& Vinnari E. (2014). A framework for sustainability transition: the case of plant-based diets. Journal of Agricultural and Environmental Ethics, 27(3), 369-396.

Vucetich, J. \& Nelson, M. (2010). Sustainability: Virtuous or vulgar? BioScience, 60(7), 539 -544.

WCED (UN W orld Commission on Environment and Development) (1987). Our Common Future: Report of the World Commission on Environment and Development. Switzerland: WCED.

Webster, A. (2002). Rendering unto Caesar: Welfare Problems in Belgian Blue Cattle. The Veterinary Journal $163,228-229$.

WHO (2009). Global health risks: mortality and burden of disease attributable to selected major risks. World Health Organization, Geneva, Switzerland.

Wirsenius, S., Hedenus, F., M ohlin, K., (2011). Greenhouse gas taxes on animal food products: rationale, tax scheme and climate mitigation effects. Climatic Change, 108(1), 159-184.

WWF (2016). Living Planet Report 2016. Risk and resilience in a new era. WWF International, Gland, Switzerland. 
Table 1. Sustainability M atrix

\begin{tabular}{|c|c|c|c|}
\hline Ethical theory & $\begin{array}{l}\text { Overall } \\
\text { objective }\end{array}$ & Interest group & Sustainability objective \\
\hline \multirow{3}{*}{ Utilitarianism } & \multirow{3}{*}{$\begin{array}{l}\text { Efficient } \\
\text { allocation }\end{array}$} & Wildlife & Increasing efficiency of natural resource usage \\
\hline & & Farmed animals & Increasing animal welfare \\
\hline & & Human animals & $\begin{array}{l}\text { Increasing the well-being of current and future } \\
\text { human generations }\end{array}$ \\
\hline \multirow{3}{*}{ Deontology } & \multirow{3}{*}{$\begin{array}{l}\text { Sustainable } \\
\text { scale }\end{array}$} & Wildlife & Limiting the land used for human purposes \\
\hline & & Farmed animals & Advancing animal rights \\
\hline & & Human animals & $\begin{array}{c}\text { Advancing the rights of present and future } \\
\text { human generations to an unpolluted } \\
\text { environment }\end{array}$ \\
\hline \multirow{3}{*}{$\begin{array}{l}\text { Moral } \\
\text { Egalitarianism }\end{array}$} & \multirow{3}{*}{$\begin{array}{l}\text { Fair } \\
\text { distribution }\end{array}$} & Wildlife & Preserving biodiversity \\
\hline & & Farmed animals & Ethical consistency in human-animal relations \\
\hline & & Human animals & $\begin{array}{l}\text { Advancing fair intra- and intergenerational } \\
\text { distribution of wealth }\end{array}$ \\
\hline
\end{tabular}

Table 2. Comparison between Sustainability M atrix and traditional framework of sustainable development

\begin{tabular}{|c|c|c|}
\hline Interest group & Sustainability objective & $\begin{array}{l}\text { Counterpart in the traditional } \\
\text { framework of sustainable development }\end{array}$ \\
\hline Wildlife & $\begin{array}{c}\text { Increasing efficiency of natural resource } \\
\text { usage }\end{array}$ & $\begin{array}{l}\text { Environmental objective: natural } \\
\text { resources }\end{array}$ \\
\hline Farmed animals & Increasing animal welfare & None \\
\hline Human animals & $\begin{array}{l}\text { Increasing the well-being of current and } \\
\text { future human generations }\end{array}$ & Overarching objective of the framework \\
\hline Wildlife & $\begin{array}{l}\text { Limiting the land used for human } \\
\text { purposes }\end{array}$ & $\begin{array}{l}\text { Environmental objective: natural } \\
\text { resources }\end{array}$ \\
\hline Farmed animals & Advancing animal rights & None \\
\hline Human animals & $\begin{array}{l}\text { Advancing the rights of present and } \\
\text { future human generations to an } \\
\text { unpolluted environment }\end{array}$ & None explicitly \\
\hline Wildlife & Preserving biodiversity & Environmental objective: biodiversity \\
\hline Farmed animals & $\begin{array}{l}\text { Ethical consistency in human- animal } \\
\text { relations }\end{array}$ & None \\
\hline Human animals & $\begin{array}{l}\text { Advancing fair intra- and } \\
\text { intergenerational distribution of wealth }\end{array}$ & $\begin{array}{l}\text { Principle associated with trade-offs } \\
\text { between societal and economic } \\
\text { objectives }\end{array}$ \\
\hline
\end{tabular}




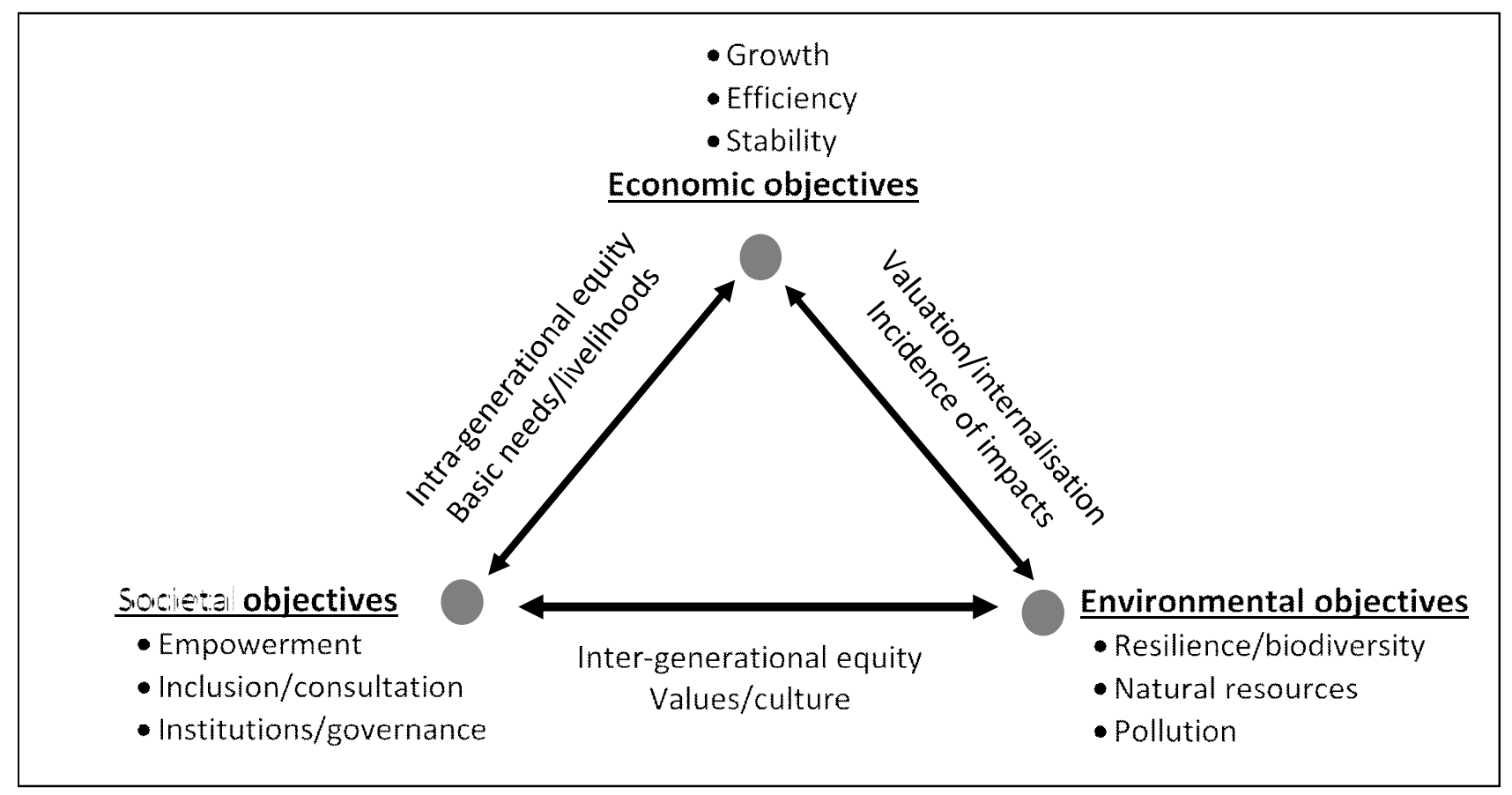

Figure 1. Predominant sustainable development framework (M unasinghe 1993)

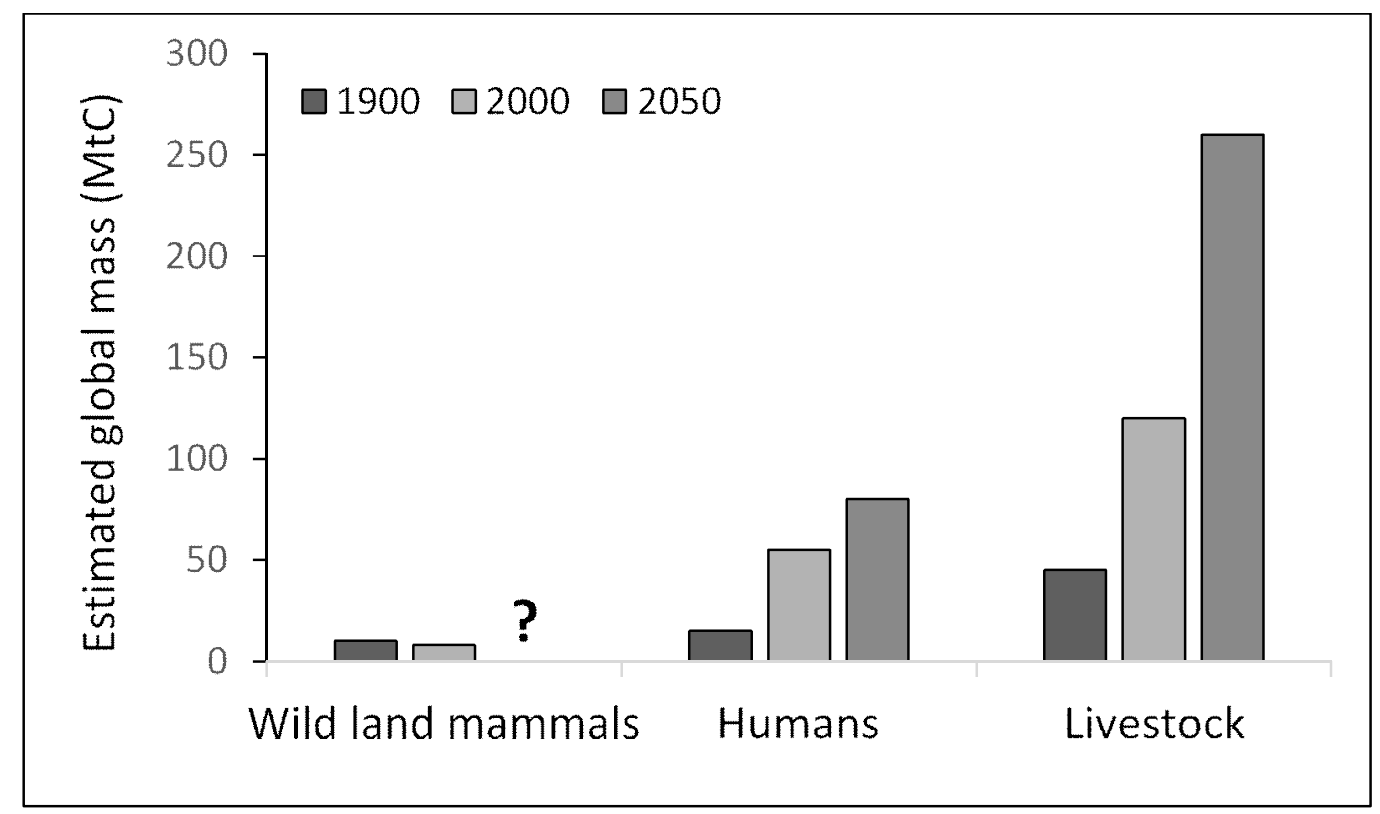

Figure 2. Global change in the collective mass for wild mammals, humans, and livestock for the years 19002050 (figure from Ripple et al. 2015) 